Tropical Journal of Pharmaceutical Research September 2017; 16 (9): 2261-2265

ISSN: 1596-5996 (print); 1596-9827 (electronic)

(C) Pharmacotherapy Group, Faculty of Pharmacy, University of Benin, Benin City, 300001 Nigeria.

All rights reserved.

Available online at http://www.tjpr.org

Original Research Article

http://dx.doi.org/10.4314/tjpr.v16i9.30

\title{
Effect of CYP2C9*3 gene polymorphism on lipid-lowering efficacy of fluvastatin in a Chinese hyperlipidemic population
}

\author{
Zhi-qiang Li ${ }^{1}$, Cai-yan $\mathrm{Li}^{2}$, Xia Wan ${ }^{1}$ and Fan Wang ${ }^{1 *}$ \\ ${ }^{1}$ Department of Neurosurgery, Jingmen No. 1 People's Hospital, ${ }^{2}$ The Center of Cancer Prevention, Jingmen No. 2 People's \\ Hospital, Jingmen, China \\ *For correspondence: Email: 2877695686@qq.com
}

Sent for review: 17 April 2017

Revised accepted: 12 August 2017

\begin{abstract}
Purpose: To investigate the frequency of gene CYP2C9*3 in Chinese populations, and to analyze the impact of CYP2C9*3 genetic polymorphism on the cholesterol-lowering effect of fluvastatin in a Chinese hyperlipidemic population.

Methods: CYP2C9 genotype was determined by polymerase chain reaction - restriction fragment length polymorphism (PCR - RFLP) in 270 unrelated hyperlipidemic patients who were treated with 80 mg fluvastatin monotherapy daily for 4 weeks and 250 healthy controls. Clinical data were collected prior to treatment with fluvastatin and 4 weeks after.

Results: In 270 hyperlipidemic patients, the frequency of CYP2C9*3 was $3.70 \%$ which is significantly higher than in 250 healthy controls $(2.60 \%)(p<0.01)$. After oral intake of fluvastatin $80 \mathrm{mg}$ daily for 4 weeks, CYP2C9*1/*3 genotype was associated with a decrease in LDL-C levels (by $33.9 \%$ in CYP2C9* $1{ }^{*} 3$ versus $24.5 \%$ for CYP2C9*1/*1, $p<0.05$ ) and with reduction of TC (by $36.4 \%$ in CYP2C9* $1{ }^{*} 3$ versus $19.4 \%$ in CYP2C9* $1{ }^{*} 1, p<0.05$ ).

Conclusion: The frequency of CYP2C9*3 is $3.17 \%$ in Chinese populations, and those who carry CYP2C9*3 mutation have a high risk of hyperlipidemia. CYP2C9*3 seems to increase the lipid-lowering effects of fluvastatin.
\end{abstract}

Keywords: Hyperlipidemia, Gene, CYP2C9, Polymorphism, Polymerase chain reaction, Restriction fragment length polymorphism, Fluvastatin

Tropical Journal of Pharmaceutical Research is indexed by Science Citation Index (SciSearch), Scopus, International Pharmaceutical Abstract, Chemical Abstracts, Embase, Index Copernicus, EBSCO, African Index Medicus, JournalSeek, Journal Citation Reports/Science Edition, Directory of Open Access Journals (DOAJ), African Journal Online, Bioline International, Open-J-Gate and Pharmacy Abstracts

\section{INTRODUCTION}

Hypercholesterolemia plays a key role in the development of atherosclerotic disease. Statins are known to reduce cardiovascular morbidity and mortality. However, there is a wide interindividual variation in response to statin therapy. The underlying causes of this phenomenon have been extensively debated, but remain uncertain [1-3]. Statins are substrates of CYP450 enzymes. Genetic polymorphisms of CYP enzymes are an important source of inter- individual variation in drug metabolism [4]. CYP2C9 is an important enzyme, and several drugs are metabolized by it, e.g., fluvastatin, simvastatin, losartan and warfarin [4-5]. Therefore, the polymorphisms of CYP2C9 may be have an effect on the above drugs' therapeutic efficacy. Any predictions of biological response of individuals to statins would thus be very valuable for more efficacious, personalized treatments. Several single-nucleotide polymerphisms (SNPs) of CYP2C9 genes have been identified. The most common mutation site in 
CYP2C9 is CYP2C9*3. Individuals who carry CYP2C9*3 gene may have reduced enzyme activity [6]. Fluvastatinis metabolized primarily by CYP2C9 [7], therefore there may be an association between CYP2C9 polymorphisms and the lipid-lowering efficacy of fluvastatin.

However, there is no report associated with CYP2C9 genotype with the efficacy of fluvastatin in Chinese peoples. Therefore, the aim of this study was to investigate the distribution of gene CYP2C9*3 relates to drug therapy and to analyze the impact of CYP2C9 gene variants on hyperlipidemia in Chinese populations.

\section{METHODS}

\section{Subjects}

From January to December, 520 non-related Chinese were randomly recruited at the Hospital of Hubei, including 270 hyperlipidemic patients (140 females, 130 males; mean age $50.35 \pm 5.85$ years) and 250 healthy volunteers (130 females, 120 males; mean age $48.21 \pm 6.35$ years). Hyperlipidemia was defined as cholesterol $>5.60$ $\mathrm{mmol} / \mathrm{L}$, triglycerides $>1.70 \mathrm{mmol} / \mathrm{L}$ or low density lipoprotein $(\mathrm{LDL})>3.20 \mathrm{mmol} / \mathrm{L}$.

Exclusion criteria were: patients with diabetes mellitus, cancer, severe endocrine diseases, hepatic disease and renal disease and those that were on therapy for any chronic inflammatory disease. This study followed the guidelines of Declaration of Helsinki [8]. The inclusion criterion for enrolment in the trial was the initiation of treatment for hypercholesterolemia with fluvastatin (80 mg monotherapy) daily. All subjects involved gave written informed consent, and the study was approved by the Ethical Committee of the Hospital of Hubei (approval ref. no. 20160101).

\section{Genotyping}

Peripheral blood samples $(2 \mathrm{~mL})$ for $C Y P 2 C 9 * 3$ genotyping were collected from all subjects. DNA was extracted from blood cells using standard protocols. CYP2C9*3 was genotyped using PCRRFLP. The pair of primers used were $5^{\prime}$ TGCACGAGGTCCAGAGGTAC - 3' and 5' AAACATGGAGTTGCAGTGTAG - $\quad 3$ '. PCR reaction was performed using $50 \mathrm{ng}$ DNA as template; the conditions of PCR reaction were: $94{ }^{\circ} \mathrm{C}$ for $5 \mathrm{~min}$, following by 35 cycles of $94^{\circ} \mathrm{C}$ for $50 \mathrm{~s}$, annealing at $60{ }^{\circ} \mathrm{C}$ for $60 \mathrm{~s}$, and extension at $72{ }^{\circ} \mathrm{C}$ for $1 \mathrm{~min}$, with a final $5 \mathrm{~min}$ extension at $72{ }^{\circ} \mathrm{C}$. The amplified DNA fragment was digested with restriction enzyme Kpn I at 37 ${ }^{\circ} \mathrm{C}$ for $12 \mathrm{~h}$. The digestion product of $\mathrm{CYP} 2 \mathrm{C} 9{ }^{*} 3$ was separated with electrophoresis on a $4 \%$ agarose gel and analysed by ethidium bromide staining.

\section{Statistical analysis}

The distribution of genotypes in the control and hyperlipidemia groups was obtained by Chisquare test. $P<0.05$ was considered statistically significant. All statistical analyses were processed using SPSS15.0 software.

\section{RESULTS}

\section{Demographic characteristics of the study population}

The characteristics of the subjects in the hyperlipidemia and control groups are shown in Table 1. Compared with control group, Age and $\mathrm{BMI}$ in the hyperlipidemia group were significantly different in the case group $(p<$ 0.05 ), while no significant difference in gender, systolic blood pressure (SBP) and diastolic blood pressure (DBP) in the two groups.

Table 1: Characteristics of study population (mean \pm SD)

\begin{tabular}{lcc}
\hline Variable & $\begin{array}{c}\text { Hyperlipidemic patients } \\
(\mathbf{n}=\mathbf{2 7 0})\end{array}$ & $\begin{array}{c}\text { Healthy control } \\
(\mathbf{n}=\mathbf{2 5 0})\end{array}$ \\
\hline Gender & 133 & 122 \\
Male & 137 & 128 \\
Female & $58.15 \pm 8.02^{*}$ & $46.59 \pm 6.23$ \\
Mean age (years) & $28.03 \pm 3.28^{*}$ & $23.56 \pm 3.01$ \\
BMl $\left(\mathrm{kg} / \mathrm{m}^{2}\right)$ & $128.52 \pm 13.28$ & $121.52 \pm 10.35$ \\
SBP $(\mathrm{mmHg})$ & $89.36 \pm 10.64$ & $82.23 \pm 9.65$ \\
DBP $(\mathrm{mmHg})$ & $4.89 \pm 1.16^{*}$ & $4.12 \pm 1.02$ \\
TC $(\mathrm{mmol} / \mathrm{L})$ & $2.85 \pm 1.06^{*}$ & $1.25 \pm 0.56$ \\
TG $(\mathrm{mmol} / \mathrm{L})$ & $0.99 \pm 0.56^{*}$ & $1.38 \pm 0.29$ \\
HDL-C (mmol/L) & $2.58 \pm 1.03^{*}$ & $2.02 \pm 0.86$ \\
LDL-C (mmol/L) & &
\end{tabular}

Compared with control, $p<0.05$ 
Table 2: Frequency of genotypes and alleles of $C Y P 2 C 9^{\star} 3$ in hyperlipidemia patients ( $\left.n, \%\right)$

\begin{tabular}{|c|c|c|c|c|c|c|}
\hline \multirow{2}{*}{$\begin{array}{l}\text { Genotype } \\
\& \text { alleles }\end{array}$} & \multicolumn{3}{|c|}{ Hyperlipidemia } & \multicolumn{3}{|c|}{ Control } \\
\hline & Male (133) & $\begin{array}{c}\text { Female } \\
\text { (137) }\end{array}$ & $n=270$ & Male (122) & $\begin{array}{c}\text { Female } \\
(128)\end{array}$ & $n=250$ \\
\hline \multicolumn{7}{|l|}{ CYP2C9*3 } \\
\hline AA & 123 (92.49) & 127 (92.70) & 250 (92.59) & 116 (95.08) & 121 (94.53) & $237(94.80)$ \\
\hline$A C$ & $10(7.51)$ & $10(7.30)$ & $20(7.41)$ & $6(4.92)$ & $7(5.47)$ & $13(5.20)$ \\
\hline CC & $0(0)$ & $0(0)$ & $0(0)$ & $0(0)$ & $0(0)$ & $0(0)$ \\
\hline C & 3.76 & 3.65 & 3.70 & 2.50 & 2.73 & 2.60 \\
\hline
\end{tabular}

Compared with control, $p<0.01$

Table 3: Effect of fluvastatin ( $80 \mathrm{mg} /$ day, 4 weeks) on TG, LDL and TC for different genotypes of CYP2C9 subjects (mean $\pm \mathrm{SD}, \mathrm{mmol} / \mathrm{L}$ )

\begin{tabular}{|c|c|c|c|c|c|c|}
\hline \multirow{2}{*}{ Variable } & \multicolumn{3}{|c|}{ CYP2C9*1*1 } & \multicolumn{3}{|c|}{ CYP2C9*1*3 } \\
\hline & $T G$ & $T C$ & $L D L-C$ & $T G$ & $T C$ & $L D L-C$ \\
\hline astatin & $2.56 \pm 1.63$ & $6.28 \pm 1.36$ & $3.64 \pm 1.02$ & $2.34 \pm 1.59$ & $6.89 \pm 1.51$ & $3.92 \pm 1.35$ \\
\hline ivastatin & $\begin{array}{c}1.65 \pm 1.32 \\
356\end{array}$ & $\begin{array}{c}5.06 \pm 0.84 \\
194\end{array}$ & $\begin{array}{c}2.75 \pm 0.58 \\
24.5\end{array}$ & $\begin{array}{c}1.42 \pm 1.28 \\
393\end{array}$ & $4.38 \pm 0.75$ & $\begin{array}{c}2.59 \pm 0.58 \\
33 a^{*}\end{array}$ \\
\hline
\end{tabular}

Compared with CYP2C9*1*1, $p<0.05$

\section{Genotype distribution of $C Y P 2 C 9 * 3$ loc}

The genotype distributions are shown in Table 2. There was no significant deviation from HardyWeinerg equilibrium in each group at $C Y P 2 C 9^{*} 3$ locus. As to CYP2C9*3 locus, the observed genotype distribution and allele frequencies differ between the hyperlipidemia and control groups $(p<0.01)$. Compared with the control group, the frequency of $T$ allele was higher in the hyperlipidemia group $(p<0.01)$.

\section{Association between genotype of CYP2C9*3 and hyperlipidemia}

In all subjects, 33 individuals carrying heterozygote for $\mathrm{CYP}_{2} \mathrm{C9}^{\star} 3$, the frequency of CYP2C9* 3 was 0.0317 , among whom were 20 subjects from 270 hyperlipidaemic patients, the allelic frequency of $\mathrm{CYP}^{2} \mathrm{CP}^{\star} 3$ was 0.037 , and 13 subjects from 250 healthy control, the allelic frequency of $\mathrm{CYP}^{2 C 9^{*} 3}$ was 0.026 . None was identified as homozygote. The frequencies of CYP2C9*3 showed significant difference between healthy control and hyperlipidaemic patients $(p<0.01)$. This indicates that $C Y P 2 C 9^{\star} 3$ is associated with hyperlipidaemia.

\section{Lipid-lowering efficacy of fluvastatin}

Fasting serum concentrations of blood lipids (inluding triglycerides, total cholesterol, and LDL cholesterol) were measured before and after the 4-week treatment with $80 \mathrm{mg}$ fluvastatin daily. In Table 3, after oral intake of fluvastatin $80 \mathrm{mg}$ daily for 4 weeks, the $C Y P 2 C 9^{*} 1{ }^{*} 3$ genotype was associated with a decrease in LDL-C levels (by $33.9 \%$ in CYP2C $^{*} 1 /{ }^{*} 3$ verse $24.5 \%$ for
CYP2C9* $\left.1 /{ }^{*} 1, p<0.05\right)$ and with the reduction of TC (by $36.4 \%$ in CYP2C9* $1 /{ }^{*} 3$ versus $19.4 \%$ in CYP2C9*1/*1). Nobody took any other lipidlowering drug. No side effects were reported among all the participants.

\section{DISCUSSION}

In this study, the frequency of $C Y P 2 C 9^{\star} 3$ was 0.0317 , which is similar to other literature reports for the Chinese [9-11]; the frequency of CYP2C9*3 was 0.043 in African-Americans, 0.10 in Spaniards [12], 0.095 in Croats [13], 0.09 in Italians [14], 0.085 in Britons [15], 0.08 in French [16], 0.067 in Russians [17], 0.066 in Swedes [18] and 0.059 in Czech population [1]. A significant difference in the distributions of CYP2C9*3 was observed between hyperlipidaemic patients and healthy individuals, but there was no statistically significant difference between male and female participants, which suggests that there is no gender difference in the distribution of $C Y P 2 C 9^{\star} 3$ in the total population.

A previous study showed that there was only a significant difference in the frequency of CYP2C9*3 between patients and healthy controls in the female group, thus strongly indicating that gender is associated with CYP2C9*3 in patients with hyperlipidaemia [10]. Our results were not consistent with the above, and it is possibly due to the diversity of the study population. However, we found that heterozygous CYP2C9*1/*3 carriers showed a greater reduction in plasma LDL-C or TC levels than wild-type subjects, which is consistent with a previous study [1]. 
CYP2C9 is a key CYP enzyme which accounts for approximately $20 \%$ of hepatic enzymes. Approximately $15 \%$ of drugs are metabolized by CYP2C9. Overall, CYP2C9 metabolizes more than 100 drugs including antidiabetic, antihypertensive, antiepileptic, anti-inflammatory drugs. Until now, over 60 different types of gene polymorphism of CYP2C9 have been reported. This suggests that individuals who carry different genotypes of CYP2C9 exhibit varying response to drugs metabolized by CYP2C9 $[19,20]$. Previous studies reported that $C Y P 2 C 9$ accounts for $50-80 \%$ of fluvastatin metabolism, which suggests that CYP2C9 gene mutation may be associated with the lipid-lowering efficacy of fluvastatin in healthy volunteers [21]. CYP2C9*3 allele is the most common mutation, which result in decreased metabolic enzyme activity and impaired metabolism of substrate drugs [22].

CYP2C9 genetic polymorphisms are an important variation in drug metabolism which metabolized including losartan, S-warfarin, phenytoin, hypoglycemic drugs and antiinflammatory drugs [4]. A previous study showed that patients carrying CYP2C9*3 showed a higher lipid-lowering efficacy against TC and LDL compared with wild-type of CYP2C9, but no significant difference exist in the frequency of adverse drug reactions in patients who carry different CYP2C9 genotypes; this suggests that CYP2C9 polymorphism associated with the lipidlowering efficacy of fluvastatin in hyperlipidemic patients [23]. Another study showed that subjects carrying CYP2C9*3 have increased the risk of adverse effects of 2.5-times, while patients who carry CYP2C9*3 and are receiving CYP2C9 inhibitors have a risk of adverse effects of 6times compared with those who were treated with the inhibitor [24].

A study reported that $C Y P 2 C 9 * 3$ and gender contribute to inter-subject variability in pitavastatin pharmacokinetics and that personalized medicine should be necessary for hypercholesterolaemic patients receiving pitavastatin [25]. Patients who carried CYP2C9 heterozygous for CYP2C9*3 allele had higher plasma levels of fluvastatin, which can increase the incidence of adverse events.

SNP causes changes in the functions of CYP enzyme which results unexpected and serious adverse drug reactions. Therefore, CYP gene polymorphism can be used as a genome biomarker for predicting adverse drug reactions. Thus, compared with healthy controls, the frequency of $C Y P 2 C 9 * 3$ is significantly higher in hyperlipidemic patients, which illustrates that those with $C Y P 2 C 9{ }^{*} 3$ mutation show a high risk for hyperlipidemia. Thus, CYP2C9*3 polymorphism is closely related to the lipidlowering efficacy of fluvastatin in patients with hyperlipidemia, suggesting that people with CYP2C9*3 mutation should exercise caution in order to avoid developing hyperlipidemia, and personalized medicine should be necessary for such hyperlipidemia patients.

\section{Limitations of the study}

In this study, the sample size of participants was small, and therefore, the results may be biased. Hence, a larger-sample study needs to be undertaken.

\section{CONCLUSION}

The frequency of CYP2C9*3 in Chinese populations is $3.17 \%$, and those with $C Y P 2 C 9{ }^{*} 3$ mutation have high risk of hyperlipidemia. CYP2C9*3 seems to enhance the lipid-lowering effects of fluvastatin.

\section{DECLARATIONS}

\section{Acknowledgement}

The authors thank Wei-ye Wang, Huazhong of University of Science and Technology for expert technical help.

\section{Conflict of Interest}

No conflict of interest associated with this work.

\section{Contribution of Authors}

The authors declare that this work was done by the authors named in this article and all liabilities pertaining to claims relating to the content of this article will be borne by them.

\section{Open Access}

This is an Open Access article that uses a funding model which does not charge readers or their institutions for access and distributed under the terms of the Creative Commons Attribution License (http://creativecommons.org/licenses/by/ 4.0) and the Budapest Open Access Initiative (http://www.budapestopenaccessinitiative.org/rea d), which permit unrestricted use, distribution, and reproduction in any medium, provided the original work is properly credited. 


\section{REFERENCES}

1. Buzková H, Pechandová K, Danzig V, Vareka T, Perlik F, Zak A, Slanar O. Lipid-lowering effect of fluvastatin in relation to cytochrome P450 $2 C 9$ variant alleles frequently distributed in the Czech population. Med Sci Monit 2012; 18(8): 512-517.

2. Yasar U, Sain-Guven G, Yardimci Y, Kilicarslan A, Babaoglu MO, Bozkurt A. Effect of atorvastatin on CYP2C9 metabolic activity as measured by the formation rate of losartan metabolite in hypercholesterolaemic patients. Basic Clin Pharmacol Toxicol 2011; 109(2): 73-77.

3. Chatzizisis YS, Koskinas KC, Misirli G, Vaklavas C, Hatzitolios A, Giannoglou GD. Risk factors and drug interactions predisposing to statin-induced myopathy: implications for risk assessment, prevention and treatment. Drug Saf 2010; 33: 171-187.

4. Zhou SF, Liu JP, Chowbay B. Polymorphism of human cytochrome $P 450$ enzymes and its clinical impact. Drug Metab Rev 2009; 41: 89-295.

5. Botton MR, Hutz MH, Suarez-Kurtz G. Influence of the CYP2C9*3 allele on the pharmacological interaction between warfarin and simvastatin. Pharmacogenom 2012; 13(14): 1557-1559.

6. Keskitalo JE, Pasanen MK, Neuvonen PJ, Niemi M. Different effects of the ABCG2 c.421C>A SNP on the pharmacokinetics of fluvastatin, pravastatin and simvastatin. Pharmacogenom 2009; 10(10): 1617-1624.

7. Korhonova M, Doricakova A, Dvorak Z. Optical Isomers of Atorvastatin, Rosuvastatin and Fluvastatin Enantio specifically Activate Pregnane $X$ Receptor PXR and Induce CYP2A6, CYP2B6 and CYP3A4 in Human Hepatocytes. PLoS One 2015; 10(9): e0137720.

8. World Medical Association. World Medical Association Declaration of Helsinki: Ethical Principles for Medical Research Involving Human Subjects. Seoul: From the 59th World Medical Association Assembly 2008; www.wma.net/en/30publications/10policies/b3/17c.pdf.

9. Xie HG, Prasad HC, Kim RB, Stein CM. CYP2C9 allelic variants: ethnic distribution and functional significance. Adv Drug Deliv Rev 2002; 54(10): 1257-1270.

10. Luo $\mathrm{CH}$, Wang A, Zhu RH, Zhang WX, Mo W, Yu BN, Chen GL, Ou-Yang DS, Duan XH, Abd El-Aty AM, Zhou $\mathrm{HH}$. Gender specific association of $\mathrm{CYP}^{2} \mathrm{C}^{*} 3$ with hyperlipidaemia in Chinese. Br J Clin Pharmacol 2005; 60(6): 629-631.

11. Ding $Y$, Yang $D$, Zhou L, He $P$, Yao J, Xie $P$, Lin $D$, Sun $D$, Sun P, Li Q, Geng T, Jin T. Cytochrome P450 2 C9 (CYP2C9) polymorphisms in Chinese Li population. Int $\mathrm{J}$ ClinExp Med 2015; 8(11): 21024-21033.

12. Dorado P, Berecz R, Norberto MJ, Yasar U, Dahl ML, LLerena A. CYP2C9 genotypes and diclofenac metabolism in Spanish healthy volunteers. Eur J Clin Pharmacol 2003; 59(3): 221-225.

13. Bozina N, Granić P, Lalić Z, Tramisak I, Lovrić M, Stavljenić-Rukavina A. Genetic polymorphisms of cyto- chromes P450: CYP2C9, CYP2C19, and CYP2D6 in Croatian population. Croat Med J 2003; 44(4): 425-428.

14. Scordo MG, Caputi AP, D'Arrigo C, Fava G, Spina E. Allele and genotype frequencies of CYP2C9, CYP2C19 and CYP2D6 in an Italian population. Pharmacol Res 2004; 50(2): 195-200.

15. Stubbins MJ, Harries LW, Smith G, Tarbit MH, Wolf CR. Genetic analysis of the human cytochrome $P 450$ CYP2C9 locus. Pharmacogenetics 1996; 6(5): 429-439.

16. Yang $J Q$, Morin $S$, Verstuyft $C$, Fan $L A$, Zhang $Y, X u C D$, Barbu V, Funck-Brentano $C$, Jaillon $P$, Becquemont $L$. Frequency of cytochrome P450 2C9 allelic variants in the Chinese and French populations. Fundam Clin Pharmacol 2003; 17(3): 373-376.

17. Gaikovitch EA, Cascorbi I, Mrozikiewicz PM, Brockmöller $J$, Frötschl R, Köpke K, Gerloff T, Chernov JN, Roots I. Polymorphisms of drug-metabolizing enzymes CYP2C9, CYP2C19, CYP2D6, CYP1A1, NAT2 and of Pglycoprotein in a Russian population. Eur $J$ ClinPharmacol 2003; 59(4): 303-312.

18. Yasar U, Eliasson E, Dahl ML, Johansson I, IngelmanSundberg $M$, Sjöqvist $F$. Validation of methods for CYP2C9 genotyping: frequencies of mutant alleles in a Swedish population. BiochemBiophys Res Commun 1999; 254(3): 628-631.

19. Hiratsuka M. Genetic Polymorphisms and in Vitro Functional Characterization of CYP2C8, CYP2C9, and CYP2C19 Allelic Variants. Biol Pharm Bull 2016; 39(11): 1748-1759

20. Rettie AE, Jones JP. Clinical and toxicological relevance of CYP2C9: drug-drug interactions and pharmacogenetics. Annu Rev Pharmacol Toxicol 2005; 45: 477-494.

21. Kirchheiner J, Kudlicz D, Meisel C, Bauer S, Meineke I, Roots I, Brockmöller J. Influence of CYP2C9 polymorphisms on the pharmacokinetics and cholesterol-lowering activity of (-)-3S,5R-fluvastatin and (+)-3R,5S-fluvastatin in healthy volunteers. Clin Pharmacol Ther 2003; 74(2): 186-194.

22. Zhou SF, Zhou ZW, Huang M. Polymorphisms of human cytochrome P450 $2 C 9$ and the functional relevance. Toxicol 2010; 278(2): 165-188.

23. Lin J, Zhang $Y$, Zhou H, Wang X, Wang W. CYP2C9 Genetic Polymorphism is a Potential Predictive Marker for the Efficacy of Rosuvastatin Therapy. Clin Lab 2015; 61(9): 1317-1324.

24. Miroševic Skvrce N, Božina N, Zibar L, Barišic I, Pejnovic L, Macolic Šarinic. VCYP2C9 and ABCG2 polymorphisms as risk factors for developing adverse drug reactions in renal transplant patients taking fluvastatin: a case-control study. Pharmacogenom 2013; 14(12): 1419-1431.

25. Zhou $Q$, Chen $Q X$, Ruan ZR, Yuan $H$, Xu HM, Zeng $S$. CYP2C9*3(1075A > C), ABCB1 and SLCO1B1 genetic polymorphisms and gender are determinants of intersubject variability in pitavastatin pharmacokinetics. Pharmazie 2013; 68(3): 187-194. 